\title{
Dramatic Irony
}

Jennifer Martini, MD

(Fam Med. 2022;54(3):228-9.)

doi: 10.22454/FamMed.2022.154897

$\mathbf{M}$ $\mathrm{y}$ eldest child is an observant, inquisitive 6 year-old, and our dinner conversations often pivot around her questions about a word she has heard us use or a concept that has puzzled her. During one such conversation last week, she focused in on a word I had offhandedly mentioned as we discussed a book together.

"Mommy," she asked, "what does 'ironic' mean?"

She got an answer that was more than she bargained for, but it was one that led me to reflect on what I had learned in college about the different types of irony that manifest themselves in life and literature. She seemed most fascinated by the concept of dramatic irony-the type of irony where the audience of a book or play knows something crucial that the protagonist does not. My mind settled there as well.

Earlier that week I received a lab result for one of my favorite patients, who had gone to the emergency department for vague abdominal pain. Mr. B. has a gentle spirit, a toothy and effervescent smile even when his COPD brings him wheezing through the exam room door, a gaggle of adorable grandchildren, and an open posture that quickly endears him to everyone in his presence. His pain had since resolved, but his imaging had shown some concerning areas in his prostate and worrisome lesions in his spine. I had asked him to come by the office for some labs before our follow-up appointment.

With trepidation, I had clicked on his result-a prostate-specific antigen value that had been flagged with a foreboding red exclamation point. It was over 1,000 , and each of its four digits struck me like successive punches in the gut. I briefly debated calling him with the likely diagnosis that day, but ultimately decided to keep our plan to review it in person the following week. For one weekend, I knew how significantly Mr. B.'s life was about to change, and he, headed out for a much-anticipated fishing trip with his grandson, did not. Dramatic irony in real life was weighing on me heavily.

As I reflected on the vulnerability of our respective positions in that moment, I could not help but draw parallels to my life almost a year ago, as my colleagues, my family, and I optimistically embarked upon 2020 at the same time that a virus already on its way to forever altering our world was insidiously propagating. Our existence then was not all that dissimilar from $\mathrm{Mr}$. B.'s this weekend-though our future had been sealed and our arduous journey determined, we hurtled toward it obliviously cloaked in routine, mundanity, and comfort.

The tally of losses and heartache that followed has long since surpassed being truly quantifiable. Some felt quite concrete, like the raw, quaking tears of a close friend whose infant son passed away in the PICU while Sponge Bob flickered on the TV in the adjacent room, or the elegiac melody of a French song that opened the Zoom funeral of the beloved clinical psychologist at my former residency program. Other wounds felt one step removed, but no less tragic-a coworker's brother whose zest for life shone through the photograph and description of his nonprofit work in his obituary; a 96-year-old patient who described telling her intubated daughter that she loved her for the last time on an iPad. And if others were less personally intimate, they were equally heart wrenching on a more global scale, and marked by the countless lives that were shortened, oppressed, and ravaged by the collision of an unforgiving disease with unjust systems whose reckoning and dismantling remain long overdue.

Sitting in this moment, with the veil of that former dramatic irony long since cast off, I find myself now focused on uncovering different information, which thus far seems to have been largely withheld from us as the battered characters in this somber narrative. In overt and subtle ways, many of my colleagues and I are grappling with big questions: How do we find peace and purpose

From the Department of Family Medicine, University of North Carolina at Chapel Hill. 
in our work after our connection and agency have been so fundamentally upended? What is there to offer in the face of such pervasive pain and injustice? How can we heal others when we ourselves remain raw and reeling? In short, the age-old question, "Why am I here?" seems harder than ever to answer with conviction, and there is a longing among many of us for the veil of this dramatic irony to be lifted.

Of course, real-life narratives are often not as succinctly structured as Shakespearean plays, and what is perhaps most simultaneously daunting and inspiring about this moment is that there is not a just or satisfying explanation. Rather, the answers to these hard questions are ours to craft, to earn, and to be worthy of. But, if we look closely at the medicine we practice and the lives with which we are intertwined as healers, we will find many small moments that provide us with inspiration, and possibly with answers that, ironically, have been there all along.

One such moment came for me as I looked into the tearful eyes of Mr. B. on that Monday morning after disclosing his test results and probable terminal disease. I had mistakenly assumed that the dramatic irony in his story was resolved after my revelation. However, Mr. B. was not the only protagonist who was unaware of information that was missing in a larger narrative. As he shifted contemplatively in his chair and rested his grey-haired head heavily in his hands, Mr. B. looked up at me and said haltingly, "Doc, this is terrible and it's not going to be easy. But I'll tell you one thing, I sure am glad you're here to do it with me."

CORRESPONDENCE: Address correspondence to Dr Jennifer Martini, Assistant Professor, University of North Carolina at Chapel Hill, Department of Family Medicine, 590 Manning Drive, Chapel Hill, NC 27599. 862-754-2240. Fax: 919-966-6126. jennifer_martini@med. unc.edu. 